\title{
Inelastic Buckling Strength of Stepped I-Beams at Midspan Subjected to Uniform Bending
}

\author{
Alolod, Shane*, and Park, Jong Sup**
}

\begin{abstract}
Lateral-torsional buckling strengths of stepped beams at the midspan have been incorporated in the structural design codes. However, these existing equations are based on the elastic theory for doubly-symmetric sections and give only a rough approximation. In addition, previous research using elastic and inelastic analyses was conducted only for stepped beams at the ends of supports. Thus, the aim of this study is to investigate and develop a general formulation for the inelastic lateral-torsional buckling strength equation of doubly symmetric stepped I-beams at midspan and to evaluate the optimum case considering the increase in buckling strength versus increase in volume of steel. A finite element analysis program, ABAQUS, and a regression program, MINITAB 17, were used to derive equations for the buckling capacities of the stepped beams. The results showed differences ranging from $-5.6 \%$ to $8.6 \%$, which are found to be reasonable estimates. The proposed equation can be further used to extend the study for evaluation under different loading conditions.
\end{abstract}

Key words : Lateral-Torsional Buckling, Stepped Beams, FEM, Inelastic Buckling

\section{요 지}

최근 구조설계기존에서 제시하는 횡-비틀림 좌굴강도 방정식은 지간 중앙을 보강한 경우에 대해 탄성이론을 기반으로 하는 대략적인 근사값을 제공하고 있으며, 비탄성 거동특성을 고려한 대부분의 연구들은 양단 또는 일단에 스텝보 보강이 있는 경우에 대해서 설계식을 제안하고 있다. 따라서 본 연구는 양단 단순보 경계조건을 가지는 지간 중앙에 스텝보 보강된 이축대칭 I형보의 비탄성 횡-비틀림 좌굴 강도를 산정하기 위한 새로운 설계식을 개발제안하고, 좌굴강도 비교를 통해 최적 단면을 산정하고자 한다. 유한요소해석 프로그램 ABAQUS와 회귀분석프로그램 MINITAB 17이 사용되었으며, 방정식과 해석결과의 비교 오차율은 $-5.5 \%$ 에서 $8.6 \%$ 범위에 해당한다. 제안된 설계식은 안전측으로 다양한 하중조건에도 적용가능하며, 상세 하중조건에 따른 추가적인 모멘트구배계수식 개발에 본 제안식이 적극 활용될 수 있다.

핵심용어 : 횡-비틀림 좌굴, 스텝보, 유한요소해석, 비탄성 좌굴

\section{Introduction}

Beams subjected to flexure have much greater strength and stiffness in the plane in which the loads are applied than in the plane of the minor principal axis. When these members are not properly braced laterally, lateral-torsional buckling may occur prior to the attainment of their full in-plane capacity. This instability occurs when a structural member undergoes significant out-of-plane bending and twisting. Another factor that contributes to the buckling of beams is initial imperfection, which commonly occurs in the fabrication phase for hot rolled beams. In a study of Roorda (1986), initial imperfections such as residual stresses and initial geometric imperfections have caused premature buckling of beams. One method to prevent this type of instability is stepping of beams. It is the sudden increase of beam cross-section at the critical area to increase its flexural resistance. This is done by increasing the cross section of the critical area rather than increasing the section throughout the span, resulting to a more cost-efficient section. Steps

\footnotetext{
*Member, Master Student, Department of Civil Engineering, Sangmyung University(E-mail: shane.alolod@gmail.com)

**Corresponding Author, Member, Professor, Department of Civil Engineering, Sangmyung University

(Tel: +82-41-550-5314, Fax: +82-41-550-5313, E-mail: jonpark@smu.ac.kr)
} 
in beams are achieved by either adding cover plates to beam flanges, changing the size of the cross section for hot rolled beams or by changing the flange dimension for built up sections.

Stepped beams have been prominently studied in the field of structural engineering. The Australian Standard (AS 4100, 1998) have presented the elastic moment capacity equation for simply supported segment in uniform bending and introduced a reduction factor to account for the varying cross-section. Trahair and Kitipornchai (1971) investigated the effect of lateral torsional buckling (LTB) on simply supported beam stepped at midspan. These equations are only limited to linear elastic analysis in which initial imperfections are neglected. Inelastic analysis was conducted by Park and Park (2013b) which focuses on the lateral torsional buckling capacity of doubly and singly stepped beams located at the end of supports.

This paper aims to further explore and extend the study on lateral torsional buckling of stepped beams at midspan under the inelastic region. Stepped beam modifier, $C_{i s t}{ }^{\prime}$, was introduced in the design equation, to consider the effect of the change in cross-section. The results were then compared to the finite element analysis results. In addition, this paper aims to assess the most effective case in terms of the increase in buckling capacity versus the amount of steel increase due to stepping of beams.

\section{Background and Previous Studies}

American Institute of Steel Construction (AISC, 2011) specifications provide equation for inelastic lateral torsional buckling resistance of prismatic beams:

$$
M_{n}=\left[M_{p}-\left(M_{p}-0.7 F_{y} S_{x}\right)\left(\frac{L_{b}-L_{p}}{L_{r}-L_{p}}\right)\right]<M_{p}
$$

where $M_{p}$ is the plastic moment; $L_{b}$ is the unbraced length; $L_{p}$ and $L_{r}$ are the limiting length for inelastic range, respectively; and $F_{y}$ is the minimum yield stress of the type of steel being used.

Since the AISC formulation is limited to prismatic beams, several studies have been conducted to formulate equations for buckling capacity of non-prismatic sections. Andrade et al. (2007) assessed the lateral torsional buckling behavior of singly symmetric web-tapered thin-walled I-beams, where he conducted a comparative study involving critical load factors and buckling modes using one dimensional model and two-dimensional shell finite element analyses. Australian
Standard AS 4100 provides equation for elastic buckling resistance of beams with varying cross-section considering a reduction factor, $\alpha_{s t}$. Trahair and Kitipornchai (1971) started tabulated solutions on elastic lateral torsional buckling of I-beams with stepped flanges. Park and Stallings (2003, 2005) conducted series of study focusing on the elastic lateral torsional buckling of stepped beams under simple conditions, stepped beams with continuous lateral bracing, and also considering the length-to-height ratio of the beam. In these studies, stepped sections of the beam were located at both ends of the beam. Lellep and Kraav (2011) focused on the elastic buckling capacity of stepped beams having piece wise dimensions with cracks. Park and Oh (2009) developed elastic buckling solution for singly symmetric stepped beams considering varying loading conditions. Recently, Santos et al. (2017) suggested an equation for elastic lateral torsional buckling of stepped beams located at midspan under general loading conditions.

Premature buckling initiated by imperfections such as residual stresses and geometric imperfection causes reduction on the buckling capacity of beams. However, the AISC specification as shown in Eq. (1) and in researches with elastic analyses, do not usually consider the residual stress and geometric imperfections. Influence of these imperfections on inelastic buckling behavior of structural steel beams have been studied vigorously by Galambos (1963) and Lindner (1974). Szalai and Papp (2005) proposed residual stress pattern that are applicable for stability problems including torsional and warping effects. Presently, computer aided methods have been widely acknowledged by researchers to investigate inelastic instability considering various sets of parameters. These were then used by Trahair and Hancock (2004), Taras and Greiner (2010), Kucukler et al. (2015), and Mohebkhah and Azandariani (2016) to analyze the inelastic behavior of beams.

Son and Park (2009) presented a design equation to calculate the inelastic lateral torsional buckling strength of stepped beams by introducing a new stepped beam modification factor, $C_{i s t}$. Park et al. (2012) extended the research by considering the load height effects. Park and Park (2013b) proposed an equation that can be used in predicting the inelastic lateral torsional capacity of doubly stepped beams at both ends and singly stepped beams at one end.

$$
\begin{aligned}
& M_{i s t}=C_{b} C_{s t} M_{i c r} \\
& C_{i s t}=1+0.7 \alpha^{2}\left(\beta \gamma^{1.05}-1\right)
\end{aligned}
$$


where $C_{i s t}$ is the stepped beam correction factor for singly stepped beams; $M_{i c r}$ is the inelastic LTB strength of beam using Eq. (1); and $\alpha, \beta$, and $\gamma$ are the stepped parameters. These equations were used as reference by Surla and Park (2014) for inelastic flexural strength trends of monosymmetric stepped beams subjected to design loading conditions. Experimental studies for inelastic for monosymmetric stepped I-beams have been published by Park and Park (2013a), and Surla and Park (2015). Recently, Sadiqali and Krishnan (2017) studied the buckling load effect to stepped beams for the optimization of stepped beams against lateral torsional buckling.

\section{Inelastic Finite Element Modeling}

Finite element analyses were conducted to evaluate the buckling moment of stepped I-beams using a Finite Element program ABAQUS (2013). Reduced integration linear shell elements (S4R) was used to model the beams due to its capability to provide enough degrees of freedom to clearly model the buckling deformations of the beam.

The prismatic and compact beam sections of $\mathrm{W} 30 \times 253$ and W36 $\times 160$ generally used in the building and bridges were investigated, that were based from the AISC specification (AISC, 2011) with corresponding properties listed in Table 1. These sections represent structural members that are used for horizontal and vertical structures. The effects of length-to-height ratio $\left(\mathrm{L}_{b} / \mathrm{h}\right)$ and stepped beam parameters such as, relative length, a, relative flange width, $b$, and relative thickness, g, as shown in Fig. 1, were considered in the analysis. These parameters are based on the study of Park and Kang (2004) in which they presented 27 typical cases of stepped beam as listed in Table 2. A total of 216 beam models were performed to develop a design equation for obtaining the LTB moment resistance of stepped beams.

Table 1. Beam Properties

\begin{tabular}{l|c|c}
\hline \multicolumn{1}{c|}{ Properties } & $\mathrm{W} 30 \times 253$ & $\mathrm{~W} 36 \times 160$ \\
\hline Flange width, $b_{f}(\mathrm{~mm})$ & 382.4 & 304.8 \\
\hline Flange thickness, $t_{f}(\mathrm{~mm})$ & 38.1 & 25.4 \\
\hline Web thickness, $t_{w}(\mathrm{~mm})$ & 21.0 & 16.5 \\
\hline Beam depth, $d(\mathrm{~mm})$ & 795.0 & 914.4 \\
\hline Modulus of Elasticity, $E(\mathrm{GPa})$ & 210 & 210 \\
\hline Yield stress, $F_{y}(\mathrm{MPa})$ & 280 & 280 \\
\hline
\end{tabular}

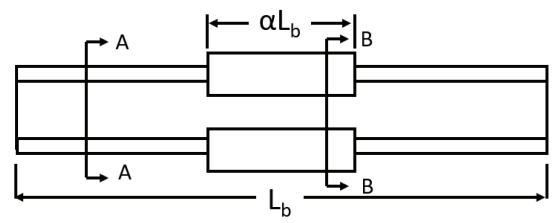

(a) Elevation View

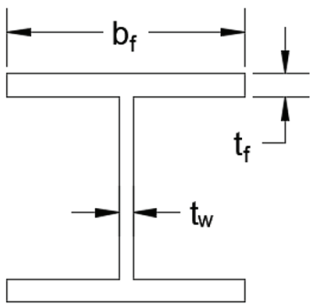

(b) Section A-A

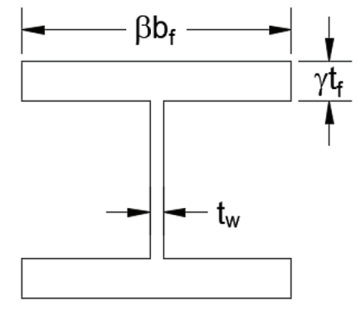

(c) Section B-B
Fig. 1. Stepped Beam Parameters Illustration

Table 2. Stepped Beam Parameters

\begin{tabular}{c|c|c|c}
\hline Cases & $\begin{array}{c}\text { Length } \\
(\alpha)\end{array}$ & $\begin{array}{c}\text { Flange width } \\
\beta\end{array}$ & $\begin{array}{c}\text { Flange Thinkness } \\
(\gamma)\end{array}$ \\
\hline $\mathrm{C} 1-\mathrm{C} 3$ & 0.167 & 1.0 & $1.2,1.4,1.8$ \\
\hline $\mathrm{C} 4-\mathrm{C} 6$ & 0.167 & 1.2 & $1.0,1.4,1.8$ \\
\hline $\mathrm{C} 7-\mathrm{C} 9$ & 0.167 & 1.4 & $1.0,1.4,1.8$ \\
\hline $\mathrm{C} 10-\mathrm{C} 12$ & 0.25 & 1.0 & $1.2,1.4,1.8$ \\
\hline $\mathrm{C} 13-\mathrm{C} 15$ & 0.25 & 1.2 & $1.0,1.4,1.8$ \\
\hline $\mathrm{C} 16-\mathrm{C} 18$ & 0.25 & 1.4 & $1.0,1.4,1.8$ \\
\hline $\mathrm{C} 19-\mathrm{C} 21$ & 0.333 & 1.0 & $1.2,1.4,1.8$ \\
\hline $\mathrm{C} 22-\mathrm{C} 24$ & 0.333 & 1.2 & $1.0,1.4,1.8$ \\
\hline $\mathrm{C} 25-\mathrm{C} 27$ & 0.333 & 1.4 & $1.0,1.4,1.8$ \\
\hline
\end{tabular}

According to the AISC Specifications (AISC, 2011) the buckling failure of the beam depends on its unbraced length, $L_{b}$, such that beams with $L_{b}$ between the limiting lengths, $L_{p}$ and $L_{r}$, develop inelastic buckling instability. Thus, the unbraced lengths that were used in the analyses were $5.0 \mathrm{~m}$ $\left(\mathrm{L}_{\mathrm{b}} / \mathrm{h}=6.61\right), 8.0 \mathrm{~m}\left(\mathrm{~L}_{\mathrm{b}} / \mathrm{h}=10.57\right), 11.0 \mathrm{~m}\left(\mathrm{~L}_{\mathrm{b}} / \mathrm{h}=14.53\right)$, and $13.0 \mathrm{~m}\left(\mathrm{~L}_{\mathrm{b}} / \mathrm{h}=17.18\right)$ for $\mathrm{W} 30 \times 253$ and $5.0 \mathrm{~m}\left(\mathrm{~L}_{\mathrm{b}} / \mathrm{h}\right.$ = 5.6), $6.0 \mathrm{~m}\left(\mathrm{~L}_{\mathrm{b}} / \mathrm{h}=6.8\right), 7.0 \mathrm{~m}\left(\mathrm{~L}_{\mathrm{b}} / \mathrm{h}=7.9\right)$, and $8.0 \mathrm{~m}$ $\left(\mathrm{L}_{\mathrm{b}} / \mathrm{h}=9.0\right)$ for $\mathrm{W} 36 \times 160$.

Stepped beams were subjected to uniform bending moment. The initial imperfections of residual stress and geometric imperfection based on the studies by Trahair and Kitpornchai (1971) and Avery and Mahendran (2000) were realistically applied to the model in order to have a more accurate inelastic model as shown in Fig. 2. 


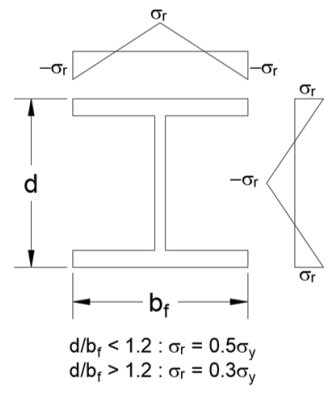

(a) Residual Stress

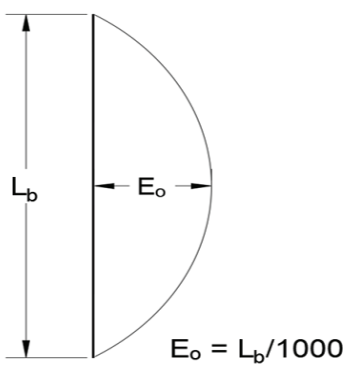

(b) Initial Out-of-Straightness
Fig. 2. Initial Imperfections

To check the accuracy of the finite element models, the obtained strengths of prismatic beams from the finite element model were compared to the strengths calculated using equations from AISC. The comparisons are shown in Figs. 3 (a) and (b).

The graph show similar trend of results although the values obtained from the FEM are quite lower than the results obtained from AISC equations. Such discrepancies in the results may be due to the assumptions of residual stresses and deformations which were not accounted by the AISC.

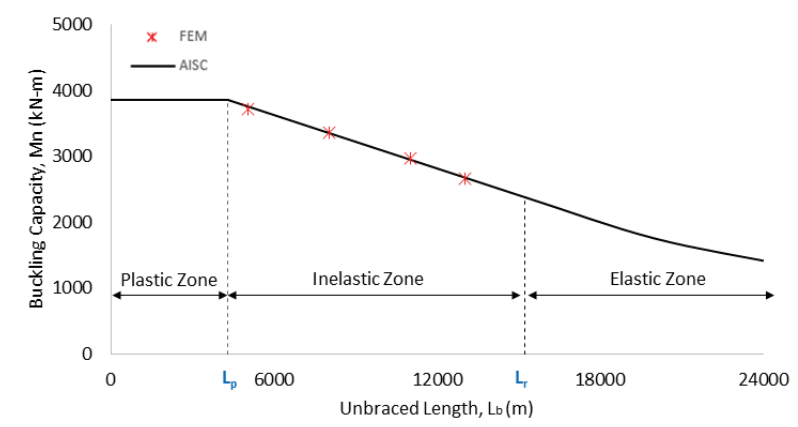

(a) $\mathrm{W} 30 \times 253$

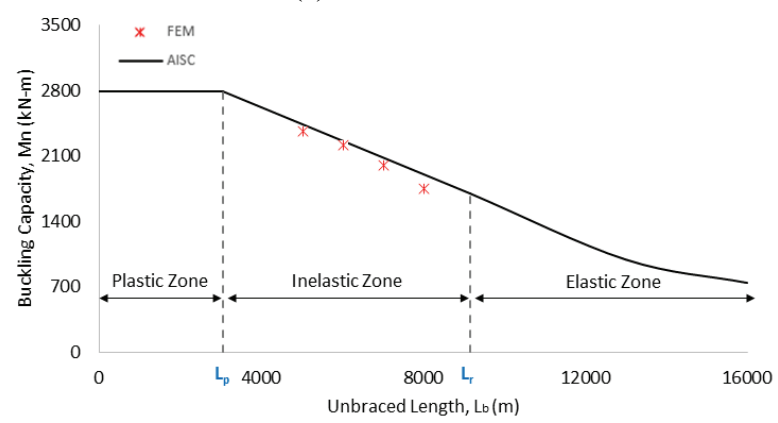

(b) $\mathrm{W} 36 \times 160$

Fig. 3. Comparison of Strength Curve

\section{Results}

\subsection{Lateral Torsional Buckling of Stepped Beams}

Parametric analyses were conducted to determine the relationship between all the parameters previously discussed and the lateral torsional buckling strengths of stepped I-beams. Stepped beams having 216 models with unbraced lengths of $5.0 \mathrm{~m}, 8.0 \mathrm{~m}, 11.0 \mathrm{~m}$, and $13.0 \mathrm{~m}$ for $\mathrm{W} 30 \times 253$ and $5.0 \mathrm{~m}, 6.0 \mathrm{~m}, 7.0 \mathrm{~m}$, and $8.0 \mathrm{~m}$ for W36 $\times 160$ were investigated. The buckling moment results from ABAQUS (2013) were used to compute the stepped beam correction factor, $C_{i s t}{ }^{\prime}$, which is defined as the ratio between the inelastic moment capacity of the stepped beam and the inelastic buckling capacity of the prismatic beam having the smaller section subjected to pure bending. A statistical software, MINITAB 17 (2014), was used for developing the new design equation.

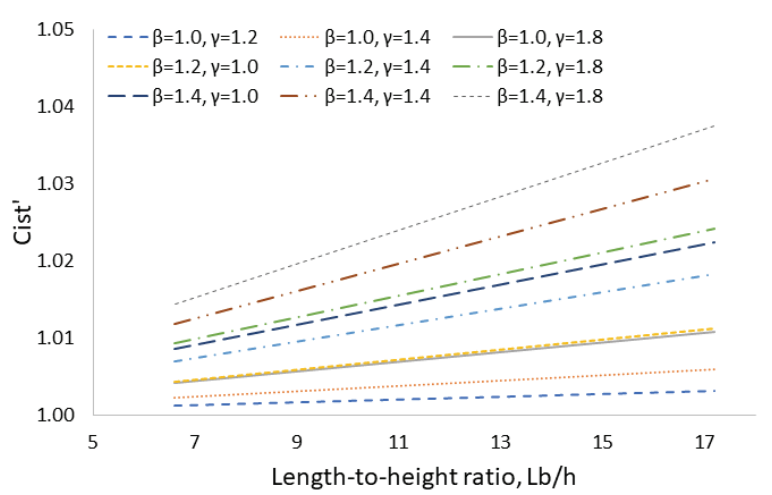

(a) $\alpha=0.167$ of $\mathrm{W} 30 \times 253$

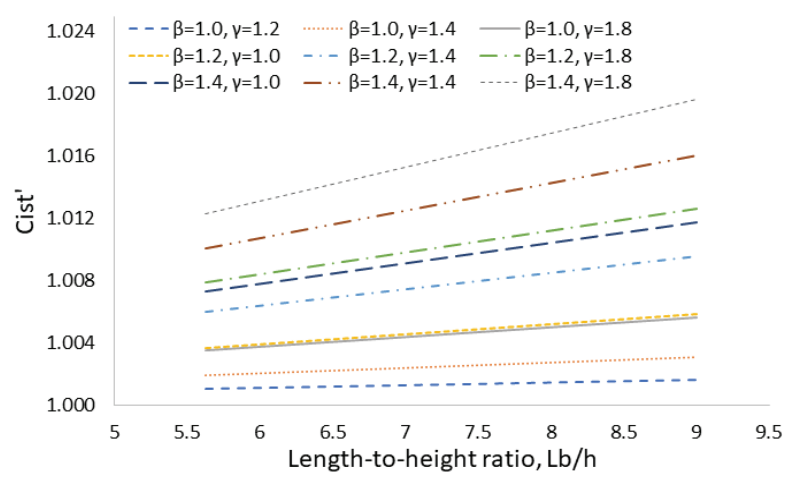

(b) $\alpha=0.167$ of $\mathrm{W} 36 \times 160$

Fig. 4. Effect of Length-to-Height Ratio to Buckling Strength

According to Park (2004), the ratio of length over height of stepped beam has a significant effect to its buckling strength. Such that as the length-to-height ratio of stepped beams increases, the LTB moment resistance also increases. The effect of length-to-height ratio is shown in Fig. 4 Thus, this factor was incorporated in the proposed equation.

The proposed inelastic lateral torsional buckling equation for doubly symmetric stepped I-beam at midspan subjected to pure bending is: 


$$
\begin{aligned}
& M_{i s t}{ }^{\prime}=C_{i s t}{ }^{\prime} M_{n} \\
& C_{i s t}{ }^{\prime}=1+\frac{L_{b}}{3.5 h} \alpha^{2.5}\left(\beta \gamma^{0.3}-1\right)
\end{aligned}
$$

where $M_{n}$ is the inelastic lateral-torsional buckling capacity of prismatic beam from Eq. (1); $C_{i s t}{ }^{\prime}$ is the inelastic stepped beam correction factor; and $\alpha, \beta$ and $\gamma$ are the stepped beam factors.

In the proposed equation, the resulting stepped beam correction factor will always be greater than 1.0. This suggests that the inelastic lateral torsional buckling of stepped beams is greater than that of prismatic beams.

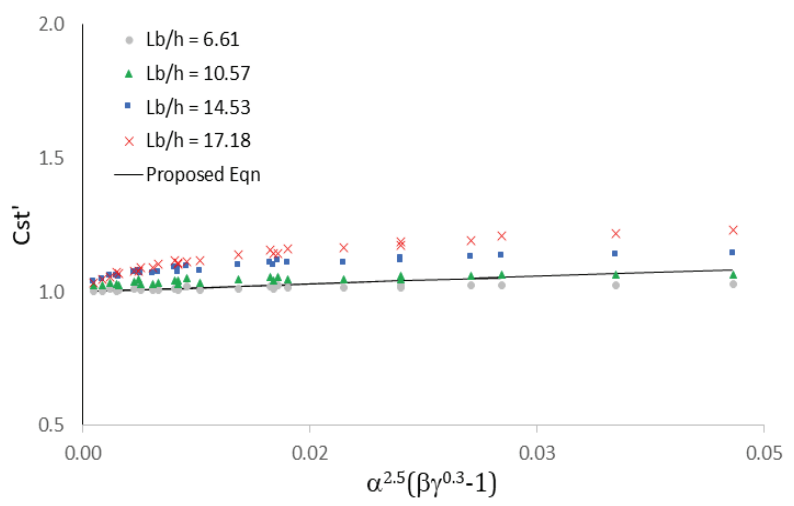

(a) for $\mathrm{W} 30 \times 253$

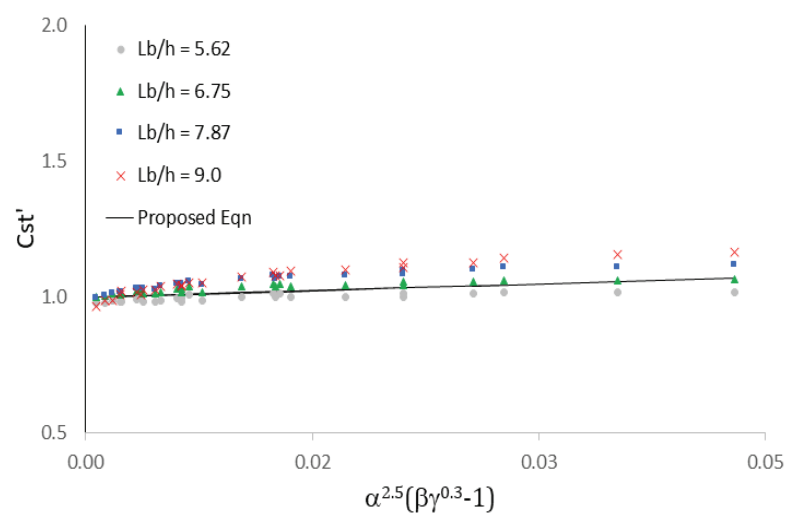

(b) for $\mathrm{W} 36 \times 160$

Fig. 5. Comparison between FEM Results and Proposed Equation

Fig. 5 presents a comparison between the results of finite element model (FEM) and Eq. (4) for W30×253 and W36 $\times 160$ stepped beams at midspan with $\mathrm{L}_{\mathrm{b}} / \mathrm{h}$ of $6.61,10.57,14.53$, and 17.18; and 5.62, 6.75, 7.87, and 9.0, respectively. Different shapes represents individual FEM results that were plotted by dividing the critical moment from the FEM analysis by the torsional buckling capacity of prismatic beam as defined in Eq. (1); and the solid line represents $C_{i s t}{ }^{\prime}$ from Eq. (5). The graph shows that $C_{i s t}{ }^{\prime}$ varies linearly with $\alpha^{2.5}\left(\beta \gamma^{0.3}-1\right)$. It can also be seen that the highest LTB strength increase in stepped beam were beams with $\mathrm{L}_{\mathrm{b}} / \mathrm{h}=17.18$ and 9.0 for $\mathrm{W} 30 \times 253$ and $\mathrm{W} 36 \times 160$, respectively.

Figs. 6 - 9 display values of $C_{i s t}{ }^{\prime}$ plotted against $\gamma$ (stepped flange thickness) for $\mathrm{W} 30 \times 253$. In those figures, line graph corresponds to stepped beam correction factor computed using Eq. (5) while bar graph represents stepped beams retrieved from finite element analysis. The results showed minimal percent difference with mostly conservative estimate. The maximum conservative estimate difference is $8.60 \%$ at $\mathrm{C} 21$ of $\mathrm{L}_{b} / \mathrm{h}=17.18$ and maximum unconservative estimate of $-5.64 \%$ at $\mathrm{C} 27$ of $\mathrm{L}_{\mathrm{b}} / \mathrm{h}=10.57$. Similar trend were observed in $\mathrm{W} 36 \times 160$, with maximum conservative estimate difference of $6.81 \%$ at $\mathrm{C} 23$ and $\mathrm{C} 24$ of $\mathrm{L}_{\mathrm{b}} / \mathrm{h}=$ 9.0 and maximum unconservative estimate of $-4.33 \%$ at $\mathrm{C} 27$ of $\mathrm{L}_{\mathrm{b}} / \mathrm{h}=5.62$.

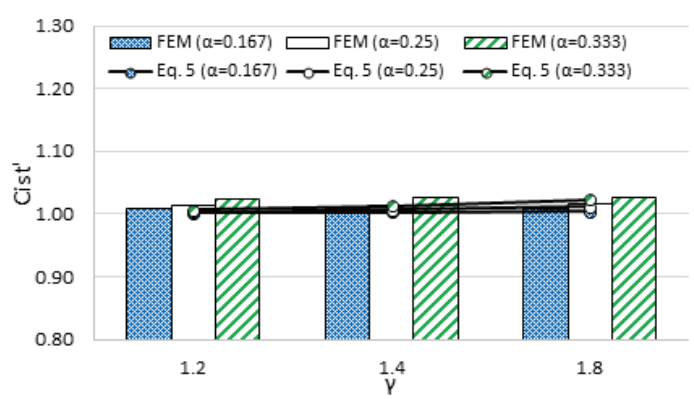

(a) $\beta=1.0$

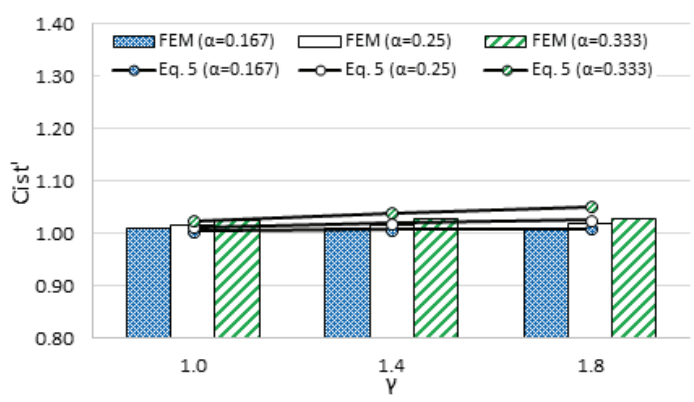

(b) $\beta=1.2$

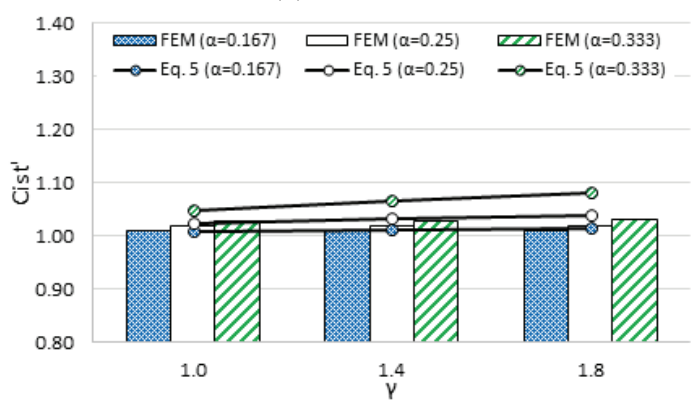

(c) $\beta=1.4$

Fig. 6. $C_{i s t}{ }^{\prime}$ for Inelastic Buckling for $L_{b}=5 \mathrm{~m}$ 


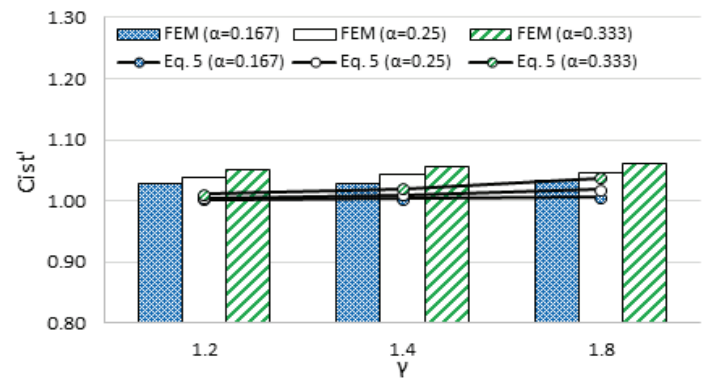

(a) $\beta=1.0$

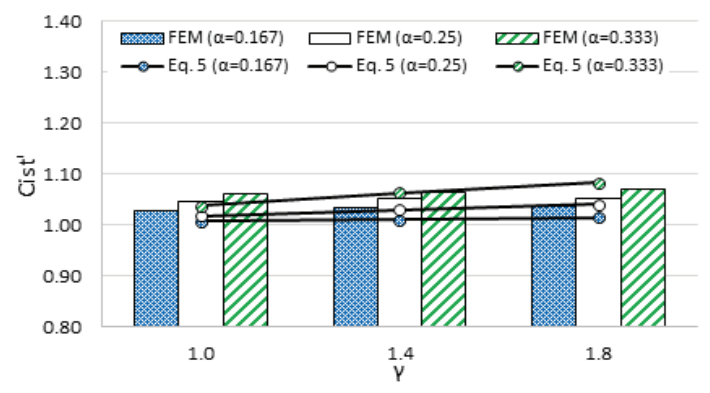

(b) $\beta=1.2$

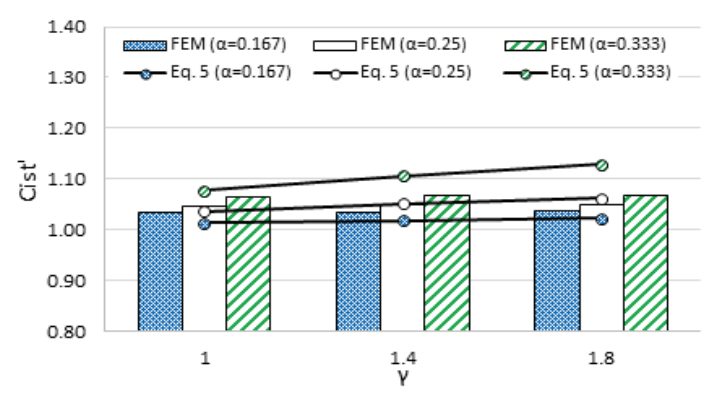

(c) $\beta=1.4$

Fig. 7. $C_{i s t}{ }^{\prime}$ for Inelastic Buckling for $L_{b}=6 \mathrm{~m}$

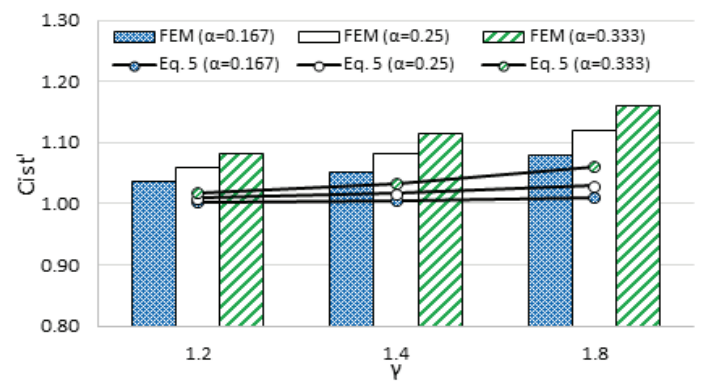

(a) $\beta=1.0$

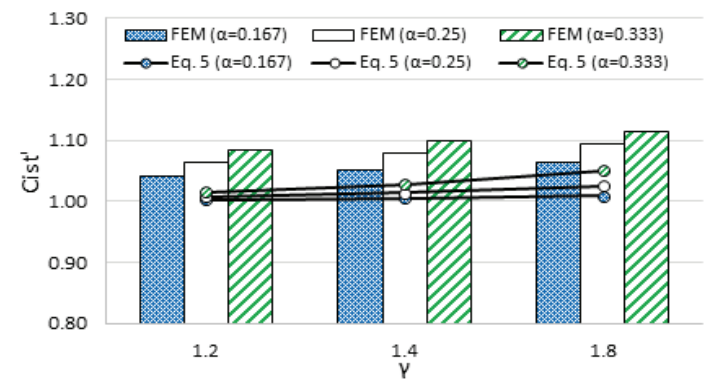

(a) $\beta=1.0$

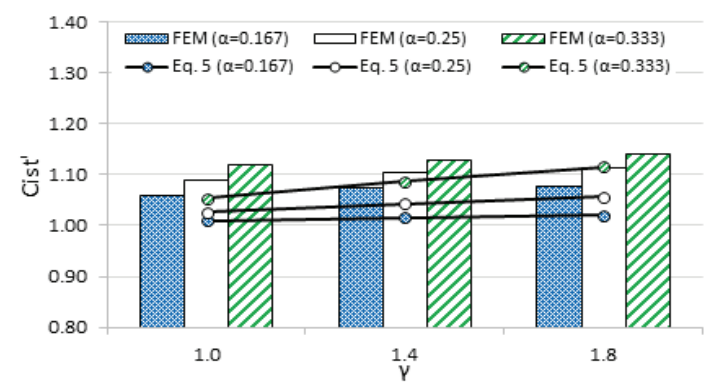

(b) $\beta=1.2$

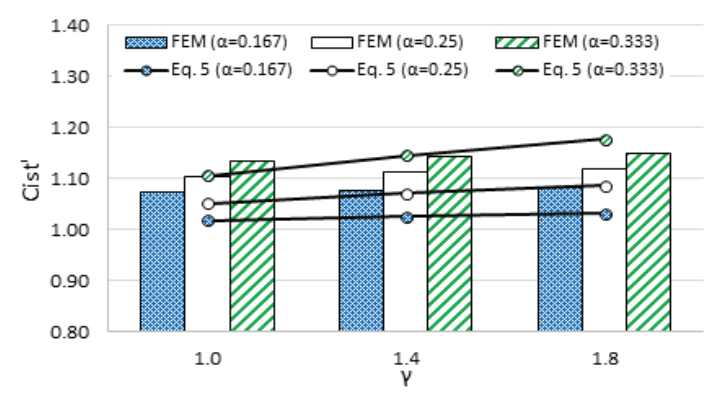

(c) $\beta=1.4$

Fig. 8. $C_{i s t}{ }^{\prime}$ for Inelastic Buckling for $L_{b}=7 \mathrm{~m}$

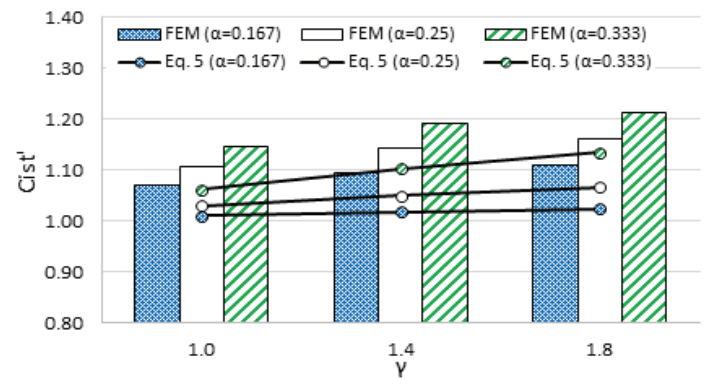

(b) $\beta=1.2$

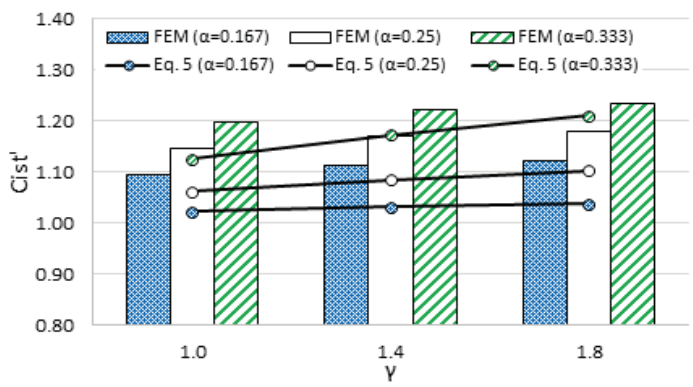

Fig. 9. $C_{i s t}{ }^{\prime}$ for Inelastic Buckling for $L_{b}=8 \mathrm{~m}$

(c) $\beta=1.4$ 


\subsection{Effectiveness of Stepped Beam}

27 stepped beam parameter combinations were used in the analysis for the inelastic lateral torsional buckling of stepped beam. In order to determine the most effective case, the ratio of the increase in buckling strength and the increase in steel section per cases were observed. Cases with strength-steel ratios greater or equal to 1.0 are considered effective, having buckling strength increase greater than the increase in steel material.

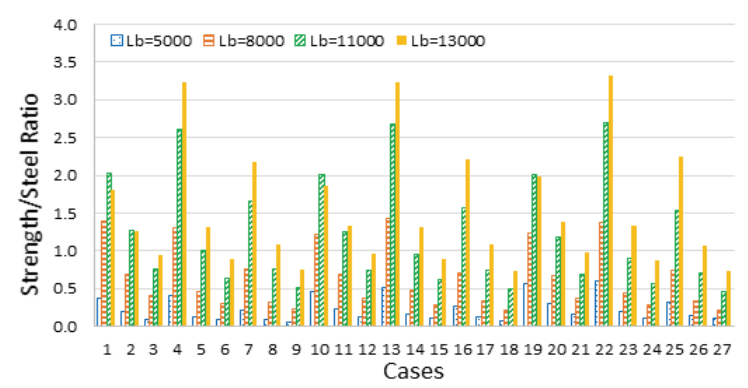

(a) $\mathrm{W} 30 \times 253$

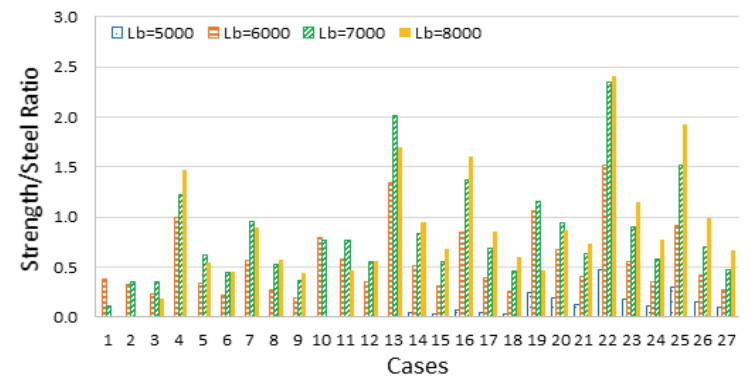

(b) $\mathrm{W} 36 \times 160$

Fig. 10. Strength-Steel Ratio of Stepped Beams

Fig. 10(a) shows that the strength-steel ratios at $\mathrm{C} 4, \mathrm{C} 13$, and C22 have values greater than 3.0 on $L_{b}=13.0 \mathrm{~m}$ and 2.5 on $11.0 \mathrm{~m}$. All these cases have a combination of $\beta=1.2$ and $\gamma=1.0$. Almost similar trend were observed on W36 $\times 160$. In Fig. 10(b) the highest ratio was on $\mathrm{C} 22$ with a value of 2.41 at $L_{b}=8.0 \mathrm{~m} . \mathrm{C} 16$ and $\mathrm{C} 25$ with combination of $\beta=1.4$ and $\gamma=1.0$; and all cases with combination of $\beta=1.2$ and $\gamma=1.0$ such as $\mathrm{C} 4, \mathrm{C} 13$, and $\mathrm{C} 22$ showed strength-steel ratios greater than 1.0 .

\section{Conclusions}

An investigation on the inelastic lateral torsional buckling behavior of stepped I-beams located at midspan subjected to pure bending was conducted using finite element method and resulted in the development of design equation. It was observed from the results of the analyses that the higher the $\mathrm{Lb} / \mathrm{h}$, the higher the increase of LTB strength of stepped beam. Thus, the length-to-height ratio of beam was then included as a parameter in the proposed equation. The comparisons between results from new design equation and FEM results showed that the proposed equation produced acceptable estimates ranging from $-5.6 \%$ to $8.6 \%$ with mostly conservative values. It was also observed that the stepped beam parameter $\gamma$ have diminutive effect on the increase in buckling strength of stepped beams.

\section{Acknowledgement}

This research was supported by the Korean Ministry of Education, Science and Technology (NRF2015-059692) and Technology Advancement Research Program (17CTAPC132629-01) funded by Ministry of Land, Transportation and Maritime Affairs of the Korean Government.

\section{References}

ABAQUS. (2013). Standard user's manual. Version 6.7, Hibbit, Karlsson and Soresen, Inc.

AISC (American Institute of Steel Construction). (2011). Steel construction manual (14th ed). AISC, USA.

Andrade, A., Camotim, D., and Dinis, P.B. (2007). Lateraltorsional buckling of singly symmetric web-tapered thin-walled I-beams: 1D model vs. shell FEA. Computer \& Structures, Vol. 85, pp. 1343-1359.

AS 4100. (1998). Steel structures. Australia Standards, Homebush, NSW, Australia.

Avery, P., and Mahendran, M. (2000). Distributed plasticity analysis of steel frames structures comprising non-compact sections. Engineering Structures, Vol. 22, pp. 901-919.

Galambos, T.V. (1963). Inelastic lateral buckling of beams. Journal of Structural Division, ASCE, Vol. 89, No. 5, pp. 217-244.

Kucukler, M., Gardner, L., and Macorini, L. (2015). Lateral-torsional buckling assessment of steel beams through a stiffness reduction method. Journal of Constructional Steel Research, Vol. 109, pp. 87-100.

Lellep, J. and Kraav, T. (2011). Elastic buckling of stepped beams with cracks. Recent Researches in Hydrology, Geology \& Continuum Mechanics, pp. 11-16.

Lindner, J. (1974). Influence of residual stress on load carrying-capacity of I-beams. Stahlbau, Vol. 43, pp. 39-45, 86-91. 
Minitab 17. (2014). Getting started with minitab 17. Minitab Inc.

Mohebkhah, A., and Azandariani, M. (2016). Lateral-torsional buckling resistance of unstiffened slender web plate girders under moment gradient. Thin-Walled Structures, Vol. 102, pp. 215-221.

Park, J.S. (2004). Lateral buckling formula of stepped beams with length-to-height ratio factor. Structural Engineering and Mechanics, Vol. 18, No. 6, pp. 745-757.

Park, J.S., and Kang, Y.J. (2004). Flexural torsional buckling of stepped beams subjected to pure bending. KSCE Journal of Civil Engineering, Vol. 8, No. 1, pp. 75-82.

Park, J.S., and Oh, J.J. (2009). Lateral-torsional buckling strength of monosymmetric doubly stepped I-beam subjected to pure bending. Journal of Korea Academia-Industrial cooperation Society, Vol. 10, No. 5, pp. 1020-1025.

Park, J.S., and Stallings, J.M. (2003). Lateral-torsional buckling of stepped beams. Journal of Structural Engineering, Vol. 129, No. 11, pp. 1457-1465.

Park, J.S., and Stallings, J.M. (2005). Lateral-torsional buckling of stepped beams with continuous bracing. Journal of Bridge Engineering, Vol. 10, No. 1, pp. 87-95.

Park, Y.S., and Park, J.S. (2013a). An experimental study on inelastic lateral-torsional buckling strength of monosymmetric stepped I-beam subjected to a concentrated load. International Journal of Advancements in Computing Technology, Vol. 5, No. 11, pp. 211-216.

Park, Y.S., and Park, J.S. (2013b). Inelastic lateral-torsional buckling strengths of stepped I-beams subjected to general loading condition. Structural Engineering and Mechanics, Vol. 48, No. 62, pp. 275-289.

Park, Y.S., Oh, J.J., Kim, K.S., and Park, J.S. (2012). A study on inelastic lateral-torsional buckling strengths with load height effects. J. Korean Soc. Hazard Mitig., Vol 12, No. 1, pp. 61-67.

Roorda, J. (1986). Buckling of elastic structures. Solid Mechanics Division, University of Waterloo Press.

Sadiqali, I.P., and Krishnan, P.A. (2017). Optimization of stepped I-beams for lateral torsional buckling.
International Journal of Advanced Research in Basic Engineering Sciences and Technology (IJARBEST), Vol. 3, No. 24, pp. 133-138.

Santos, R.R., Kang, J.S., and Park, J.S. (2017). Elastic buckling assessment of doubly symmetric I-beams with singly stepped section at midspan. J. Korean Soc. Hazard Mitig., Vol. 17, No. 6, pp. 301-312. Son, J.M., and Park, J.S. (2009). A study on moment gradient factor for inelastic lateral-torsional buckling of stepped I-beam subjected to uniformly distributed load and end moment. J. Korean Soc. Hazard Mitig., Vol. 9, No. 4, pp. 1-9.

Surla, A., and Park, J.S. (2014). Investigation of lateraltorsional buckling strength trends in monosymmetric stepped I-beams subjected to several loading conditions. J. Korean Soc. Hazard Mitig., Vol. 14, No. 4, pp. 33-41.

Surla, A., and Park, J.S. (2015). Investigation of effects of steps in inelastic-buckling strength of I-beams subjected to two concentrated loads using experimental tests, finite element analysis, and proposed equations. J. Korean Soc. Hazard Mitig., Vol. 15, No. 5, pp. 1-12.

Szalai, J., and Papp, F. (2005). A new residual stress distribution for hot-rolled I-shaped sections. Journal of Constructional Steel Research, Vol. 61, pp. 845-861.

Taras, A., and Greiner, R. (2010). New design curves for lateral torsional buckling: Proposal based on consistent derivation. Journal of Constructional Steel Research, Vol. 66, No. 5, pp. 648-663.

Trahair, N.S., and Hancock, G. (2004). Steel member strength by inelastic lateral buckling. Journal of Structural Engineering, Vol. 130, No. 1, pp. 64-69.

Trahair, N.S., and Kitipornchai, S. (1971). Elastic lateral buckling of stepped I-beams. Journal of Structural Division, Vol. 97, No. 10, pp. 2535-2548. 